\title{
Impact of distributed generation on the Nigerian power network
}

\author{
Taiwo Fasina, Bankole Adebanji, Adewale Abe, Isiaka Ismail \\ Department of Electrical and Electronic Engineering, Ekiti State University, Ado Ekiti, Nigeria
}

\begin{tabular}{l} 
Article Info \\
\hline Article history: \\
Received Jul 5, 2020 \\
Revised Sep 7, 2020 \\
Accepted Oct 17, 2020 \\
\hline
\end{tabular}

\section{Keywords:}

Distributed generation Energy storage system Network losses Power system simulation Renewable generation Voltage profile

\begin{abstract}
Distributed generations (DG) are being installed at increasing rates, both in developed and developing countries. The increasing number of DG connected to the distribution system could have a significant impact on the power system operation. This paper presents a case study investigating the impact of grid-connected DG on the Nigerian power network in terms of bus voltages and network losses. The results showed that without DG, some of the bus voltage magnitudes of the test system were outside the permissible voltage limit of $0.95 \mathrm{pu} \leq \mathrm{Vi} \leq 1.05 \mathrm{p}$.u. However, with $\mathrm{DG}$ connected, the voltage magnitudes were improved to allowable values. The network active power loss was reduced by $12.03 \%$ from $85.60 \mathrm{MW}$ to $75.30 \mathrm{MW}$. In this way, the power system becomes more efficient and secured.
\end{abstract}

This is an open access article under the CC BY-SA license.

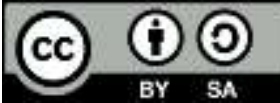

\section{Corresponding Author:}

Taiwo Fasina

Department of Electrical and Electronic Engineering

Ekiti State University, Ado Ekiti

PMB 5363, Ado Ekiti, Ekiti State, Nigeria

Email: fashtay100@gmail.com

\section{INTRODUCTION}

The electric power supply in Nigeria is problematic and unreliable. These problems include under voltages, high network losses, and frequent partial and total network collapse. Nigeria's power system has total network losses of $19 \%$ of generated power [1]. The available generation capacity in Nigeria is less than the power demand, thus resulting in power network being overloaded. Electricity demand in Nigeria is growing rapidly due to industrialization and rising population [2]. In fact, less than forty percent of Nigeria's population have access to quality electricity supply [3,4]. There are cases of occasional system collapse in the network [5]. The federal government planned to address these challenges by introducing a renewable distributed generation to the power system [6]. Distributed generation is preferred to centralized synchronous generation because it is cheaper and does not require network upgrade. Distributed generations are smallscale generation which are connected to the electricity distribution system [7]. Distributed generation can be renewable generation or small-scaled conventional generation. They are widely used in distributed generation systems such as wind turbines, solar PV, fuel cells, and storage batteries [8].

The federal ministry of power has targeted $30 \%$ electricity generation from renewable energy by 2030 [9]. In 2005, the Ministry of Power in Nigeria launched the electric power reform act 2005, which introduces feed-in-tariff (FiT) scheme to promote renewable energy generation [10]. The installation of gridconnected DG will help to overcome the current challenges facing the power system [11]. Therefore, the aim of this paper is to determine the impact of DG on the Nigerian power system. 
The design of the power system in Nigeria considered unidirectional power flow, that is, from the generating station down to the end users. This situation might lead to reverse power flow in the system when DG is connected to the power network. Therefore, it is necessary to carry out the impact study of DG on the power grid. This will help in the planning and operation of the future power system to minimize the negative impact of the DG integration. DG connected to the electricity distribution system may result in overvoltage [12], as well as overloading of power transformers and cables.

Previous studies have been carried out to determine the impact of DG on the electricity grid. For example, the impact of distributed generation with respect to voltage profile [13], line losses [14, 15], shortcircuit current [8], and harmonic [16]. Majority of the studies consider power network in the UK power systems, where the DGs are mostly wind turbines and combined heat and power (CHP) type. In Nigeria, DGs are mostly solar PV and Diesel generators. Therefore, it is necessary to carried out impact studies on the Nigerian distribution network with available DG in order to understand the potential impacts on the network. Therefore, this paper examines the impacts of DG on the Nigerian electricity distribution network with respect to network voltage and power losses using the Newton-Raphson method in the Neplan software environment.

\section{RESEARCH METHOD}

The Nigerian $330 \mathrm{kV}$ power grid shown in Figure 1 was developed using Neplan software. Power flow analysis is carried out using the Newton-Raphson solution. The input data for the power flow analysis include the generator output power, MW and MVAR peak loads, voltage, and power ratings of the line and transformer data. The modeled network is simulated with and without DG.

The network data was obtained from the power holding company of Nigeria (PHCN), interaction with PHCN staff, and transmission station at Osogbo. The limits for the distribution voltage $(330 \mathrm{kV})$ in Nigeria are $\pm 5 \%$ of nominal [17]. The single line diagram of the Nigerian $330 \mathrm{kV}$ power network is shown in Figure 1 and the transmission line data is presented in Table 1. It consists of twenty-eight load stations and nine generating stations [18]. The population in Nigeria has increased due to industrial and economic growth.

The network data was obtained from the power holding company of Nigeria (PHCN), interaction with PHCN staff, and transmission station at Osogbo. The limits for the distribution voltage (330kV) in Nigeria are $\pm 5 \%$ of nominal [17]. The single line diagram of the Nigerian $330 \mathrm{kV}$ power network is shown in Figure 1 and the transmission line data is presented in Table 1. It consists of twenty-eight load stations and nine generating stations [18]. The population in Nigeria has increased due to industrial and economic growth.

Table 1. Line parameter for $330 \mathrm{kV}$ lines

\begin{tabular}{|c|c|c|c|c|c|}
\hline From Bus & To Bus & $\mathrm{L}(\mathrm{km})$ & R (p.u) & X (p.u) & B (p.u) \\
\hline Osogbo & Ikeja & 252 & 0.0099 & 0.0745 & 0.4949 \\
\hline Osogbo & Benin & 251 & 0.0098 & 0.0742 & 0.4930 \\
\hline Egbin & Aja & 27.5 & 0.0006 & 0.0044 & 0.0295 \\
\hline Ikeja & Akangba & 17 & 0.0007 & 0.0050 & 0.0333 \\
\hline Osogbo & Ayede & 115 & 0.0045 & 0.0340 & 0.2257 \\
\hline Ikeja & Egbin & 62 & 0.0023 & 0.0176 & 0.1176 \\
\hline Ikeja & Benin & 280 & 0.0110 & 0.0828 & 0.5500 \\
\hline Ikeja & Ayede & 137 & 0.0054 & 0.0405 & 0.2669 \\
\hline Benin & Delta & 107 & 0.0043 & 0.0317 & 0.2101 \\
\hline Benin & Sapele & 50 & 0.0020 & 0.0148 & 0.0982 \\
\hline Kainji & Jebba & 81 & 0.0032 & 0.0239 & 0.1589 \\
\hline Shiroro & Kaduna & 96 & 0.0038 & 0.0284 & 0.1886 \\
\hline Afam(iv) & Alaoji & 25 & 0.0010 & 0.0074 & 0.0491 \\
\hline Ajaokuta & Benin & 195 & 0.0077 & 0.0576 & 0.3830 \\
\hline Jebba & Osogbo & 249 & 0.0061 & 0.0461 & 0.3064 \\
\hline Kaduna & Kano & 265 & 0.0090 & 0.0680 & 0.4516 \\
\hline Kaduna & Jos & 197 & 0.0081 & 0.0609 & 0.4046 \\
\hline Jos & Gombe & 265 & 0.0118 & 0.0887 & 0.5892 \\
\hline Sapele & Aladja & 63 & 0.0025 & 0.0186 & 0.1237 \\
\hline Benin & Onitsha & 137 & 0.0054 & 0.0405 & 0.2691 \\
\hline Onitsha & Newhaven & 96 & 0.0036 & 0.0272 & 0.1807 \\
\hline Delta(iv) & Aladja & 30 & 0.0012 & 0.0089 & 0.0589 \\
\hline Onitsha & Alaoji & 80 & 0.0060 & 0.0455 & 0.3025 \\
\hline Jebba G & Jebba & 8 & 0.0002 & 0.00020 & 0.0098 \\
\hline JebbaTS & Shiroro & 244 & 0.0096 & 0.0721 & 0.4793 \\
\hline Kainji & Birnin & 310 & 0.0122 & 0.0916 & 0.6089 \\
\hline Jos & Markudi & 275 & 0.0029 & 0.0246 & 0.1450 \\
\hline Ikeja & Papalanto & 45 & 0.0012 & 0.0089 & 0.0589 \\
\hline
\end{tabular}




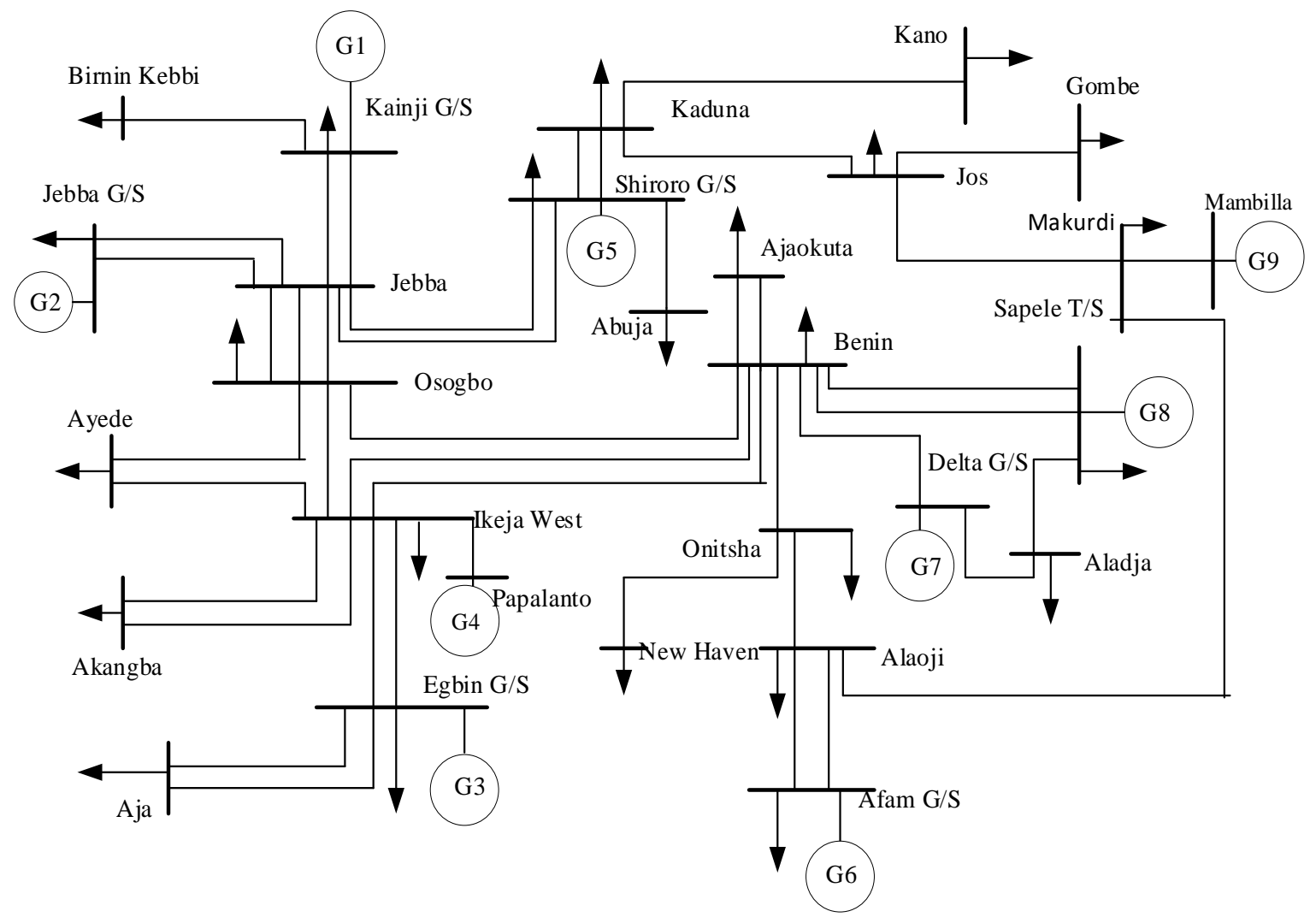

Figure 1. Nigeria power network [19], [20]

\subsection{Formulation of Power flow Equations}

In a typical bus of a power system network as shown in Figure 2. Transmission lines are represented by their equivalent $\pi$ models [21]. The current $I_{i}$ in Figure 2 is given as:

$$
\begin{aligned}
& I_{i}=y_{i 0} V_{i}+y_{i 1}\left(V_{i}-V_{1}\right)+y_{12}\left(V_{i}-V_{2}\right)+\cdots+y_{i n}\left(V_{i}-V_{n}\right) \\
& =\left(y_{i 0}+y_{i 1}+y_{i 2}+\cdots y_{i n}\right) V_{i}-y_{i 1} V_{1}-y_{i 2} V_{2}-\cdots-y_{i n} V_{n} \\
& I_{i}=V_{i} \sum_{j=0}^{n} y_{i j}-\sum_{j=1}^{n} y_{i j} V_{j} j \neq i
\end{aligned}
$$

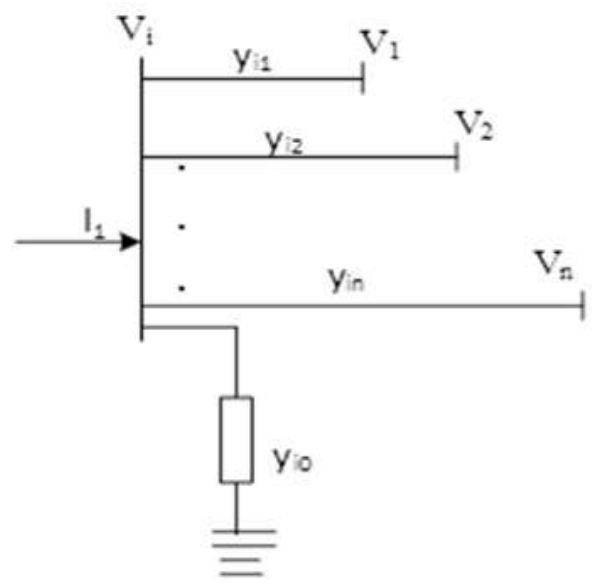

Figure 2. A typical bus of the power system [21] 
The real and reactive power at bus is:

$\mathrm{P}_{\mathrm{i}}+\mathrm{jQ} \mathrm{Q}_{\mathrm{i}}=\mathrm{V}_{\mathrm{i}} \mathrm{I}_{\mathrm{i}}^{*}$

$I_{i}=\frac{P_{i}-j Q_{i}}{V_{i}^{*}}$

Substitute for $I_{i}$ in (1):

$\frac{P_{i}-j Q_{i}}{V_{i}^{*}}=V_{i} \sum_{j=0}^{n} y_{i j}-\sum_{j=1}^{n} y_{i j} V_{j} j=\neq$

As shown above, the power flow problem can be solved by iterative techniques [21, 22].

\subsection{Newton Raphson Method}

In Figure 2, this equation can be rewritten as:

$I_{i}=\sum_{j=1}^{n} Y_{i j} V_{j}$

Expressing this equation in polar form, we have:

$\mathrm{I}_{\mathrm{i}}=\sum_{\mathrm{j}=1}^{\mathrm{n}}\left|\mathrm{Y}_{\mathrm{ij}}\right|\left|\mathrm{V}_{\mathrm{j}}\right|<\theta_{\mathrm{ij}}+\delta_{\mathrm{j}}$

Therefore:

$P_{i}-j Q_{i}=V_{i}^{*} I_{i}$

Substituting (4) for Ii in (5):

$P_{i}-j Q_{i}=\left|V_{i}\right|<-\delta_{i} \sum_{j=1}^{n}\left|Y_{i j}\right|\left|V_{j}\right|<\theta_{i j}+\delta_{j}$

Separating the real and imaginary parts:

$P_{i}=\sum_{j=1}^{n}\left|V_{i}\right|\left|V_{j}\right|\left|Y_{i j}\right| \cos \left(\theta_{i j}-\delta_{i}+\delta_{j}\right)$

$\mathrm{Q}_{\mathrm{i}}=\sum_{\mathrm{j}=1}^{\mathrm{n}}\left|\mathrm{V}_{\mathrm{i}}\right|\left|\mathrm{V}_{\mathrm{j}}\right|\left|\mathrm{Y}_{\mathrm{ij}}\right| \sin \left(\theta_{\mathrm{ij}}-\delta_{\mathrm{i}}+\delta_{\mathrm{j}}\right)$

Expanding (7) and (8) in Taylor's series, we have:

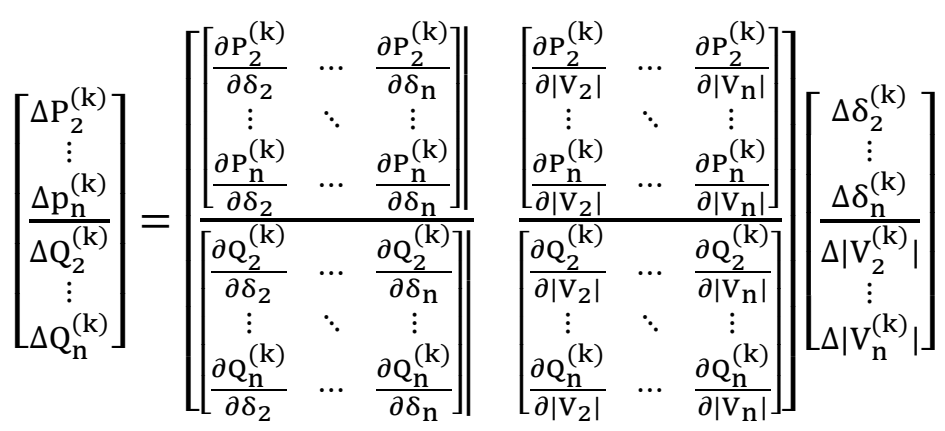

The element of the Jacobian matrix is evaluated at $\Delta \delta_{i}^{(\mathrm{k})}$ and $\Delta\left|\mathrm{V}_{\mathrm{i}}^{(\mathrm{k})}\right|$ :

$\left[\begin{array}{l}\Delta \mathrm{P} \\ \Delta \mathrm{Q}\end{array}\right]=\left[\begin{array}{ll}\mathrm{J}_{1} & \mathrm{~J}_{2} \\ \mathrm{~J}_{3} & \mathrm{~J}_{4}\end{array}\right]\left[\begin{array}{c}\Delta \delta \\ \Delta|\mathrm{V}|\end{array}\right]$

$\Delta \mathrm{P}$ and $\Delta \mathrm{Q}$ represents the difference between specified value and calculated value.

$\Delta \mathrm{V}$ and $\Delta \delta$ represents magnitude voltage and voltage angle. 


\subsection{Newton Raphson method}

The flowchart for the power flow solution by Newton-Raphson method is shown in Figure 3.

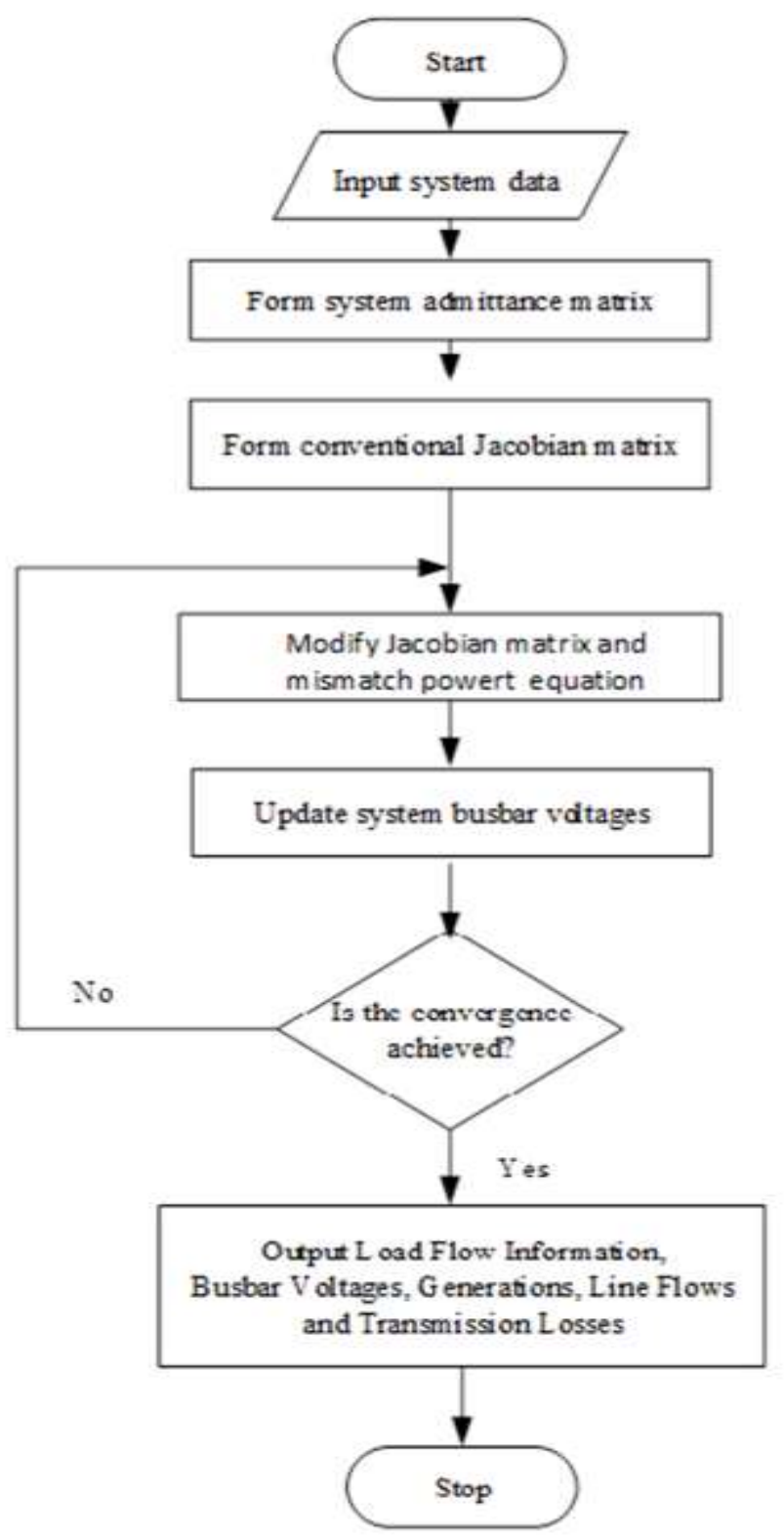

Figure 3. Power flow solution using newton raphson method

\section{RESULTS AND DISCUSSION}

In this study, all the simulations are carried out in the Neplan software environment. The first simulation is carried out with existing system data without DG. The result showed that voltage at the following buses, namely Gombe $(0.897 \mathrm{pu})$, Onitsha $(0.937 \mathrm{pu})$, New Haven $(0.946 \mathrm{pu})$, Ayede $(0.932 \mathrm{pu})$, Kano $(0.885 \mathrm{pu})$ and Jos $(0.925 \mathrm{pu})$ were outside the voltage statutory limit of $0.95 \mathrm{pu} \leq \mathrm{V}_{\mathrm{i}} \leq 1.05 \mathrm{pu}$ as shown in Table 2. The total network active power loss without DG is $85.6 \mathrm{MW}$. The results of the base case load flow providing active power losses with and without DG are shown in Figure 4. This result agree with previous studies on the network as reported in [23-25]. Therefore, incorporation of DG in the distribution network will help to alleviate the problems of voltage limit violations, and high-power loss in the system. In the second simulation, six DGs, 10MW each was connected in the network and are optimally located at the following buses, NewHaven, Ayede, Jos, Onitsha, Gombe, and Kano in Figure 1 [17]. 
The second power flow results showed that immediately the DGs were installed in the network there is redistribution of power flows and the system total active power loss reduced to $75.3 \mathrm{MW}$ (12.07\% reduction) as depicted in Figure 4. The high-power losses in the system represent a huge financial deficit to the wheeling utility. Therefore, the installation of DG will reduce the financial burden on wheeling utility. The simulation results show that Jos to Gombe transmission lines had the highest losses in the network as a result of excessive reactive power build up along the transmission lines. Reactive power flows along the line were due to a low power factor in the nodes.

Table 2. Voltage profile with and without DG

\begin{tabular}{|c|c|c|c|}
\hline $\begin{array}{l}\text { Bus } \\
\text { No }\end{array}$ & $\begin{array}{c}\text { Bus } \\
\text { Name }\end{array}$ & $\begin{array}{c}\text { Bus Voltage } \\
\text { without DG }(\mathrm{pu})\end{array}$ & $\begin{array}{l}\text { Bus Voltage } \\
\text { with DG }(\mathrm{pu})\end{array}$ \\
\hline 1 & Kainji & 1.050 & 1.050 \\
\hline 2 & Oshogbo & 1.014 & 1.021 \\
\hline 3 & Benin & 1.028 & 1.031 \\
\hline 4 & Ikeja West & 1.019 & 1.021 \\
\hline 5 & Ayede & 0.932 & 0.980 \\
\hline 6 & Jos & 0.925 & 0.968 \\
\hline 7 & Onitsha & 0.937 & 0.976 \\
\hline 8 & Akangba & 1.012 & 1.013 \\
\hline 9 & Gombe & 0.897 & 0.972 \\
\hline 10 & Abuja & 0.98 & 1.000 \\
\hline 11 & Egbin & 1.050 & 1.050 \\
\hline 12 & Delta & 1.050 & 1.050 \\
\hline 13 & Papalanto & 1.050 & 1.050 \\
\hline 14 & Mambilla & 1.050 & 1.050 \\
\hline 15 & Makurdi & 1.015 & 1.027 \\
\hline 16 & Aladja & 1.045 & 1.045 \\
\hline 17 & Kano & 0.885 & 0.965 \\
\hline 18 & Sapele & 1.050 & 1.050 \\
\hline 19 & Aja & 1.045 & 1.045 \\
\hline 20 & Ajaokuta & 1.036 & 1.040 \\
\hline 21 & New haven & 0.946 & 0.984 \\
\hline 22 & Alaoji & 1.030 & 1.033 \\
\hline 23 & Afam GS & 1.050 & 1.050 \\
\hline 24 & Jebba & 1.049 & 1.049 \\
\hline 25 & Jebba GS & 1.050 & 1.050 \\
\hline 26 & Birnin Kebbi & 1.033 & 1.033 \\
\hline 27 & Shiroro & 1.050 & 1.050 \\
\hline 28 & Kaduna & 1.012 & 1.022 \\
\hline
\end{tabular}

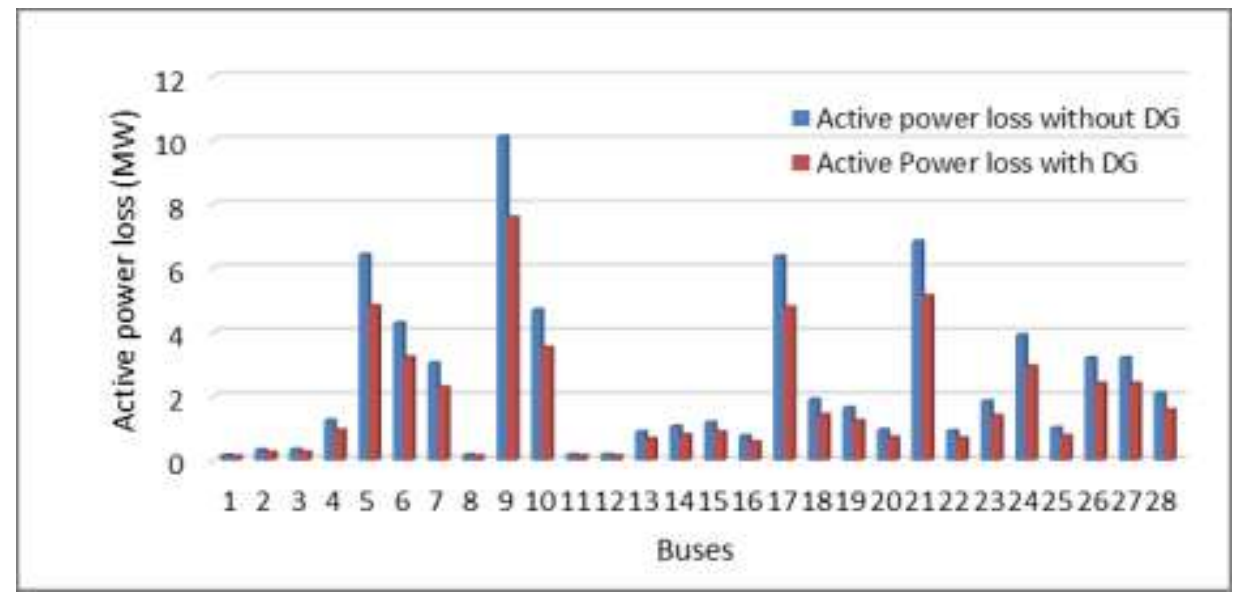

Figure 4. Active power loss in the system

\section{CONCLUSION}

In this work, load flow analysis of the Nigerian $330 \mathrm{kV}$ power network was performed using Neplan software and the buses with low voltages were identified. The ability of DG to enhance reduction in power loss and voltage improvement was demonstrated. The DGs gave a satisfactory result, raising the magnitude 
of the voltage at the buses where they were connected. Also, it raised the magnitude of voltage at other load buses sufficiently to safe operating limit of $0.95 \mathrm{pu} \leq \mathrm{V} \leq 1.05 \mathrm{pu}$, thus, enhancing network security and efficiency. The power flow analysis of the Nigerian power grid conducted showed that the power network is weak with high power loss and voltage limit violations. Moreso, when the DG is connected to the network it helps in reducing power losses in the system depending on the size and location of the DG installed. The network losses reduced by $12.07 \%$ leading to savings in the overall network cost. It is observed that at higher penetration of DG, the voltage rise problem could arise. This voltage rise problem could damage network equipment and affect network operation. The impact of DG is location-dependent, as such, in this study, the DG was optimally connected to the distribution network to avoid unnecessary voltage rise. It is expected that the results obtained will help future research in this area and assist the PHCN in network planning and maintenance.

\section{ACKNOWLEDGEMENTS}

This research work was supported in part by the Ekiti State University, Ado-Ekiti, Nigeria and the Institute of Energy, School of Engineering, Cardiff University, United Kingdom. The authors are grateful to all the staff and students of these institutions for their assistance.

\section{REFERENCES}

[1] H. N. Amadi, E. N. C. Okafor, and F. I. Izuegbunam, "Assessment of Energy Losses and Cost Implications in the Nigerian Distribution Network," American Journal of Electrical and Electronic Engineering, vol. 4, no.5, pp. 123130, 2016, doi: 10.12691/ajeee-4-5-1.

[2] A. P. Team, "Nigeria Power Baseline Report," Office of the Vice President.Federal Republic of Nigeria, 2015.

[3] A. S. Sambo, "Matching Electricity Supply with Demand in Nigeria," International Association of Energy Economics, vol. 4, pp. 32-36, 2008.

[4] A. O. Melodi and S. A. Adeoye, "Normal Mode Limitations of Existing $33 \mathrm{kV}$ Power Grid for Full Electrification of Urban and Rural Areas of Ekiti State, Nigeria "Journal of Emerging Trends in Engineering and Applied Science, vol. 4, no. 3, pp. 485-492, 2013.

[5] V. Ahiuma-Young, "2017 projections for power supply: Nigerians resign to fate as system collapses 22 times in 12 months - Vanguard News," Vanguard, 2017. [Online]. Available: https://www.vanguardngr.com/2017/01/2017projections-power-supply-nigerians-resign-fate-system-collapses-22-times-12-months/. [Accessed: 19-Apr-2018].

[6] S. O. Ogunjuyigbe, T. R. Ayodele, and O. O. Akinola, "Impact of distributed generators on the power loss and voltage profile of sub-transmission network," Journal of Electrical System and Information Technoology, vol. 3, no. 1, pp. 94-107, 2016, doi: 10.1016/j.jesit.2015.11.010.

[7] T. Ackermann and T. Ackermann, "Distributed Generation : a definition distributed generation" Electrical Power System Reviews, vol. 57, April, pp. 195-204, 2001, doi: 10.1016/S0378-7796(01)00101-8.

[8] F. K. Ariyo and M. O. Omoigui, "Investigation of nigerian $330 \mathrm{kv}$ electrical network with distributed generation penetration - part I: basic analyses," International Journal of Energy and Power Engineering, vol. 1, no. 1, pp. 120, 2014, doi: 10.11648/j.ijepe.20120101.11.

[9] SE4ALL, "Sustainable energy for all: action agenda \& investment prospectus implementation," in Presented At the 3rd Annual Workshop on Advancing SE4All Country Action in Africa Abidjan - Cote D'Ivoire 9th -12th February 2016, 2016.

[10] E. T Fasina, R.O. Oliyide and L.M. Cipcigan. "Localised energy systems in Nigeria power networks",15th International Conference on Industrial Informatics, INDIN 2017, Emdem, Germany,2017.

[11] B. Bayer, P. Matschoss, H. Thomas, and A. Marian, "The German experience with integrating photovoltaic systems into the low-voltage grids," Renewable Energy, vol. 119, pp. 129-141, Apr. 2018, doi: 10.1016/j.renene.2017.11.045.

[12] B. Kroposki et al., "Achieving a 100\% Renewable Grid," IEEE Power and Energy Magazine, vol. 15, no. 2, pp. 61-73, 2017.

[13] R. Tonkoski, D. Turcotte, and T. H. M. El-Fouly, "Impact of high PV penetration on voltage profiles in residential neighborhoods," IEEE Transaction on Sustainable Energy, vol. 3, no. 3, pp. 518-527, 2012, doi: 10.1109/TSTE.2012.2191425.

[14] K. Kirubarani and A. Peer Fathima, "Impact of distribution generation on losses of distribution system," Lecture Notes on Electrical Engineering, vol. 394, pp. 395-403, 2017, doi: 10.1007/978-981-10-1540-3_42.

[15] L. Ramesh and S. Chowdhury, "Minimization of power Loss in distribution networks by different techniques," World Academy of Science and Engineering, vol. 2, no. 1, pp. 1-6, 2009.

[16] R. Pinto, S. Mariano, R. Calado, and J. F. De Souza, "Impact of Rural Grid-Connected Photovoltaic Generation Systems on Power Quality," energies, no. Lv, vol. 9, no. 9, p. 739, 2016, doi: 10.3390/en9090739.

[17] A. O. E. and E. C. E. J. N. Nweke, "Optimal Location of Distributed Generation on the Nigerian Power Network," Nigerian Journal of Technology, vol. 35, no. 2, pp. 398-403, 2016.

[18] R. A. Jokojeje, I. A. Adejumobi, and O. I. Adebisi, "Reactive Power Compensation in Nigeria Electricity Grid Using Static Synchronous Compensator (STATCOM)," IOSR Journal of Electrical and Electronic Engineering, vol. 10, no. 2, pp .8-20, 2015, doi: 10.9790/1676-10240820. 
[19] NERC, "The Distribution Code For The Nigeria Electricity Distribution System,” 2016, pp. 1-125.

[20] D. O. Aborisade and K. . Adebayo, I.G., and Oyesina, "Open Access A comparison of the Voltage Enhancement and Loss Reduction Capabilities of STATCOM and SSSC FACTS Controllers," American Journal of Engineering Reviews, vol. 03, no. 01, pp. 96-105, 2014.

[21] H. Saadat, Power System Analysis, Third Edition. PSA Publishing, 2011.

[22] P. Kundur, Power System Stability And Control, Englewood Cliff, New Jersey: McGraw-Hill, Inc., 1994.

[23] K. A. Adebayo, I.G. Aborisade, D.O. and O. Oyesina, "Steady State Voltage Stability Enhancement Using Static Synchronous Series Compensator ( SSSC ); A Case Study of Nigerian 330KV Grid System," Journal of Engineering Application and Science, vol. 2, no. 1, pp. 54-61, 2013.

[24] O. Eseosa and E. Ogujor, "Determination of Bus Voltages, Power Losses and Flows in the Nigeria 330kV Integrated Power System," International Journal of Advances in Engineering and Technology, vol. 4, no. 1, pp. 94 106, 2012.

[25] U. C. Ogbuefi and T. C. Madueme, "A Power Flow Analysis of the Nigerian 330 KV Electric Power System," IOSR Journal of Electrical and Electronics Engineering (IOSR-JEEE) vol. 10, no. 1, pp. 46-57, 2015, doi: 10.9790/1676-10114657.

\section{BIOGRAPHIES OF AUTHORS}
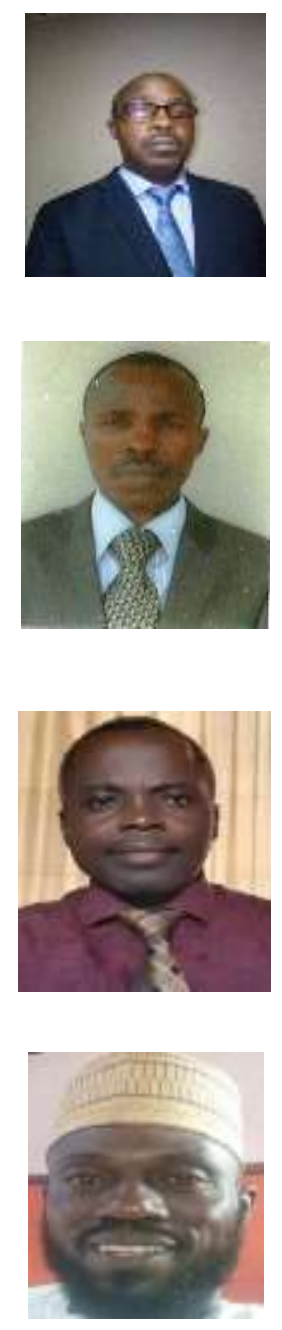

Taiwo Fasina received the B.Eng. degree in Electrical and Electronic Engineering from Ondo State University, Ado Ekiti, Nigeria (now Ekiti State University, Ado-Ekiti), in 1998 and M. Tech. degree from Ladoke Akintola University (LAUTECH), Ogbomoso, Nigeria in 2012. He completed his Ph.D. from Cardiff University, United Kingdom, in 2019. He is currently a lecturer in Ekiti State University, Ado Ekiti, Ekiti-State, Nigeria. He is a registered COREN Engineer and a member of the Nigerian Society of Engineers (MNSE). His main interest includes power system analysis, distributed generation, localised energy systems, Electric vehicles, deregulation, and electricity transmission pricing.

Bankole Adebanji received the B.Eng.degree in Electrical and Electronic Engineering in 1997 from the then Ondo State University, Ado-Ekiti, Ekiti State, Nigeria (now Ekiti State University, Ado-Ekiti), M.Tech.degree (Electronic and Electrical Engineering) and Ph.D degree ( Power System Engineering and Machine) from Ladoke Akintola University of Technology (LAUTECH), Ogbomoso, Nigeria in 2010 and 2019 respectively. His researh interest are Renewable energy, Power system engineering, Hybrid, Small hydro and optimization.He is a resgistered COREN Engineer and a member of Nigerian Society of Engineers (MNSE). He is currently lecturing in the Electrical and Electronic Engineering department of Ekiti State University, Ado-Ekiti, Nigeria.

Adewale Abe received the B.Eng.degree in Electrical and Electronic Engineering in 1999 from the then Ondo State University, Ado-Ekiti, Ekiti State, Nigeria (now Ekiti State University, AdoEkiti), M. Eng. degree (Electrical and Electronic Engineering) from University of Benin, Nigeria in 2005 and $\mathrm{PhD}$ degree (Electronic System Engineering and Machine) from University of Essex, UK in 2018. His researh interest are Electronic and Telecommunication Engineering. He is a resgistered COREN Engineer and a member of Nigerian Society of Engineers (MNSE). He is Senior lecturer in the Electrical and Electronic Engineering department of Ekiti State University, Ado-Ekiti, Nigeria.

Isiaka Ismail was born in Kano, Nigeria in 1976. He received the B. Eng degree in Electrical and Electronic Engineering from Ahmadu Bello University, Zaria, Nigeria in 2002 and M. Eng degree in Electronic and Communication Engineering from Ekiti State University, Ado Ekiti, Ekiti State, Nigeria in 2017. He is currently undergoing his PhD degree in Ladoke Akintola University of Technology, Ogbomosho, Nigeria. His research area is in speech recognition technology using artificial intelligence. 